\title{
Assessment of the Durability and Bio-effectiveness of Three Long-Lasting Insecticidal Nets in Three Different Communities After the 2017 Mass Net Distribution Campaign in Benin
}

\author{
Idelphonse Bonaventure Ahogni (Corresponding author) \\ Centre de Recherche Entomologique de Cotonou, CREC, Cotonou, Benin \\ Faculty of Sciences and Techniques, University of Abomey-Calavi, Benin \\ Tel: +22996682198 E-mail: idelphonseab2016@gmail.com

\begin{abstract}
Albert Sourou Salako
Centre de Recherche Entomologique de Cotonou, CREC, Cotonou, Benin Faculty of Sciences and Techniques, University of Abomey-Calavi, Benin E-mail: albertsourousalako@yahoo.fr
\end{abstract}

Jean-Fortuné Dagnon

President's Malaria Initiative, US Agency for International Development, Cotonou, Benin E-mail: lecuredars@yahoo.fr

\author{
Wilfrid Sèwade \\ Hacettepe university, Ankara, Turkey \\ E-mail: Sessowiles@gmail.com
}

\begin{abstract}
Prudenciène Agboho
Centre de Recherche Entomologique de Cotonou, CREC, Cotonou, Benin

E-mail: aprudincine@yahoo.fr
\end{abstract}

Germain Padonou 
Centre de Recherche Entomologique de Cotonou, CREC, Cotonou, Benin

Faculty of Sciences and Techniques, University of Abomey-Calavi, Benin

E-mail: pagergil@yahoo.fr

\author{
Martin C. Akogbeto \\ Centre de Recherche Entomologique de Cotonou, CREC, Cotonou, Benin \\ E-mail: akogbetom@yahoo.fr
}

Received: September 6, 2020 Accepted: October 9, 2020

doi:10.5296/jbls.v11i2.17645 URL: https://doi.org/10.5296/jbls.v11i2.17645

\begin{abstract}
Long-lasting insecticidal nets (LLINs) are an essential tool in the fight against malaria. Physical integrity, durability and bio-effectiveness are key variables in the effectiveness of LLINs. The objective of this study was to identify the main factors affecting the survival of three brands of LLINs with different physical characteristics and to assess their bio-effectiveness. A cohort consisting of 1500 LLINs (500 of each) of the brands: DawaPlus ${ }^{\circledR} 2.0$ (polyester, 150 denier, $40 \mathrm{~g} / \mathrm{m} 2$ fabric weight), PermaNet ${ }^{\circledR} 2.0$ and Yorkool ${ }^{\circledR}$ (polyester, 75 denier, alternating knit pattern with $85 \mathrm{~g} / \mathrm{m} 2$ fabric weight) was monitored every 6 months in the communes of Ketou, Dogbo and Djougou (from October 2017 to September 2019) based on attrition and integrity measures and median survival in years. We also determined bio-efficacy using the WHO cone test. The physical presence rate was $26.4 \%$, $21.4 \%$ and $48.6 \%$ respectively for DawaPlus ${ }^{\circledR 2.0}$, PermaNet@2.0 and Yorkool®. The main cause of loss of the three LLINs was displacement, $43.6 \%$ (in rural areas) versus $43.2 \%$ (in urban areas) with no significant difference $(\mathrm{p}>0.05)$. The median proportional hole index (pHI) ranged from 578 (IQR: 219-843) at 6 months to 196 (IQR: 46-524.5). After 24 months of use, $86.1 \%$ were in good condition $(0 \leq \mathrm{pHI}<65), 9 \%$ were damaged $(65 \leq \mathrm{pHI}<643)$ and $4.2 \%$ were too torn $(643 \leq \mathrm{pHI})$. A significant decrease in physical survival of LLINs (all brands) was observed at 24 months (37.9\%, range 34.7-41.3\%) compared to 6 months $(90.3 \%$, range $88.7-91.8 \%)(p<0.001)$. The 24-hour mortality of the three LLINs met WHO requirements for efficacy. The decline in LLIN survival rates during this study highlights the need to develop and implement new strategies to manage this important vector control tool.
\end{abstract}

Keywords: LLIN, Survivorship, Fabric integrity, bio- effectiveness

\title{
1. Introduction
}

Benin is located in West Africa in the tropical zone between the equator and the Tropic of Cancer (between the parallels $6^{\circ} 30$ 'and $12^{\circ} 30^{\prime}$ of Latitude North and the meridians $1^{\circ}$ and 
$30^{\circ} 40$ of East longitude). It has a population of around 10 million. It is limited to the North by the Niger River which separates it from the Republic of Niger; to the northwest by Burkina Faso, to the west by Togo, to the east by Nigeria and to the south by the Atlantic Ocean. The geography of Benin translates to the south by an equatorial climate with high humidity. Alternating dry seasons (November to March and mid-July to mid-September) and rainy seasons (April to mid-July and mid-September to October). In the center and north, a tropical climate. A dry season from November to April and a rainy season from June to September. This results in an additional level of complexity, when certain areas are different from access, and the epidemiology of malaria and the vector varies considerably.

The prevention of malaria using long-lasting insecticide-treated nets (LLINs), a very effective and cost-effective intervention, has increased considerably in sub-Saharan Africa in recent years. Given that many countries have now reached high LLIN coverage and are approaching the WHO goal of universal coverage of one mosquito net for two people at risk, the question of how these successes can be maintained becomes the subject of debate. Benin, compared to this objective is not late because $80 \%$ of households have a LLIN for two people (MIS, 2017). However, the importance of the durability of nets and the "average useful life" of a net is increasingly recognized as critical factors in the design of malaria control programs, as these determine the how often should the nets be replaced and what type of mosquito net to purchase (Azondekon R, et al., 2014; Gnanguenon V, et al., 2014; Hakizimana E, et al., 2014; Mansiangi P, et al., 2020). This is reflected in the WHO guidelines for monitoring LLINs in the field, which recommends that countries regularly monitor the durability of the nets.

Several studies, including a sustainability assessment of insecticide-treated nets three years later between 2011 and 2014, funded by PMI, and other financial partners indicate a rapid decline in survival in Benin and elsewhere (Azondekon R, et al., 2014; Gnanguenon V, et al., 2014; Haji, K. A., et al., 2020). the differences observed in terms of net survival are due to living conditions (at least in part), to the household environment and to household behaviors (maintenance and repair of nets) and not always to the material of LLINs (Kilian, A, et al., 2015; Ana Paula Abílio, et al., 2020). However, Emmanuel Obi in his study showed better physical integrity and acceptable survival after three years (Emmanuel Obi, et al., 2020). Thanks the massive distribution of previous campaigns, to justify, quantify and prioritize future replacement needs. This includes bioassay analysis, as WHO guidelines state that LLINs must have adequate insecticidal activity after 20 standard washes and a minimum of 3 years of regular field use, which does not is still not the case as it varies from country to country (Van Roey, K., et al., 2014; Sudhansu Sekhar Sahu, et al., 2020). Monitoring the durability of the nets focuses on three indicators: physical integrity, a quantification of the size and number of holes in the LLINs; the survival of the nets, the percentage of nets still present and used in the household to which they were distributed and the bio-efficacy, a measure of the insecticidal effect of LLINs.

Following the 2017 mass campaign, which took place in October, a sustainability study was carried out on DawaPlus $\AA^{\circledR}$.0, PermaNet ${ }^{\circledR} 2.0$ and Yorkool ${ }^{\circledR}$ LLINs (in polyester treated with deltamethrin). Three endemic regions with different socio-geographic and ecological characteristics were randomly selected: Djougou, Dogbo and Ketou (in 2017). In accordance 


\section{Ml Macrothink}

with the need for the Ministry of Health and its cell, the National Malaria Control Program (NMCP) to obtain concrete evidence of the sustainability of LLINs outside Olyset (distributed and monitored in 2011) in Benin, the objectives of this study were to follow these LLINs to identify those which are the most resistant to external pressures and those which offer better bio-efficacy. Certainly, these three types of LLIN are approved by WHOPES, but it is the first time that we have the opportunity to compare their performance in community in our country in terms of (i) assessing the motivation of the community to use LLIN distributed by estimating their loss rate; (ii) identify the main determinants influencing the loss of tissue integrity; and (iii) monitor the decrease in insecticide on the surface of the various LLINs.

\section{Materials and Methods}

\subsection{Study Sites}

This study was conducted between October 2017 and September 2019 in the cities of Djougou, Dogbo and Ketou. Between 2004 and 2014, there was a stagnation in the incidence of malaria with slight upward trends around 170 cases per 1000 population (17\%) (NMCP, 2011). In 2017, according to the Directory of health, statistics of the Ministry of Health of Benin, malaria was the main cause of consultation (44\%) and hospitalization (31\%). Its incidence rose from $17 \%$ in 2014 to $14.6 \%$ with a lethality of 0.8 per thousand in April 2017 (WHO, 2019). The main vectors of malaria are An. coluzzii, An. gambiae, funestus. All vectors are completely sensitive to pyrethroids. Figure 1 below shows the areas under study with the types of nets monitored.

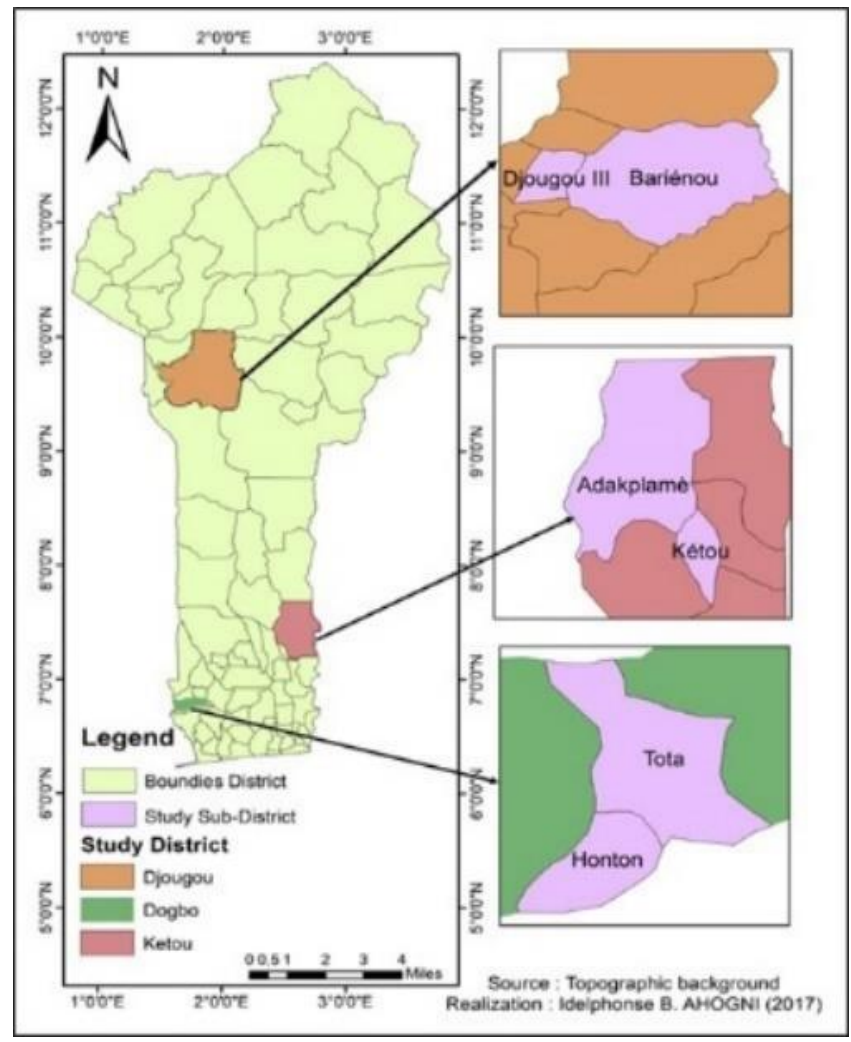

Figure 1. Location of study sites within Benin 


\subsection{Study Design}

This prospective study follows a representative cohort model that was implemented in three districts that received nets during the mass distribution campaign in October 2017 (Figure 2). Its design and implementation were based on the President's Malaria Initiative (PMI) guidelines for monitoring and evaluating the sustainability and effectiveness of LLINs in Phase 3 (WHO, 2013). The first brand was DawaPlus®2.0, which obtained the provisional recommendation of WHOPES in December 2008 and WHO prequalification in 2013 (WHO, 2019, 2011) PermaNet ${ }^{2} .0$ was the second brand in our study to receive WHO prequalification in 2017 (Kilian, A., et al., 2015) Finally, the last brand was Yorkool LLIN, which was approved in December 2009. At each follow-up, the physical integrity and the presence and/or absence of LLINs were assessed (attrition and integrity) based on a questionnaire adapted to the needs of the study with the use of damage assessment tools found during inspections. For each follow-up after the baseline, field nets per site (50), as recommended by WHO, were sampled and collected to assess the effectiveness of insecticides (WHO, 2019)

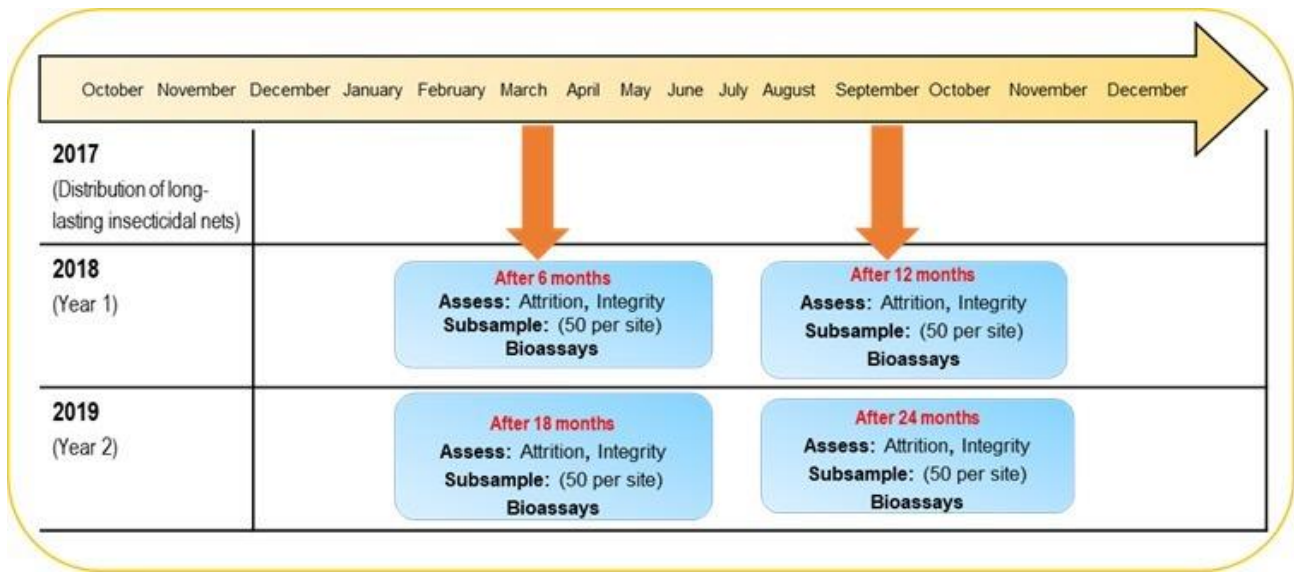

Figure 2. Follow-up program for the prospective sustainability study

\subsection{Sample Size}

The sampling of households was carried out on the basis of the total number of households in the selected villages. To this end, a cohort of nets ( 250 / type /rounding) were followed at 6 , 12, 18 and 24 months (WHO, 2013). A sample of 1,500 households, or 500 per district was selected at random. In each of the households, a field mosquito net was identified. The selection of households on each site took into account all the villages to ensure representative sampling. The evaluation teams inspected the LLINs, if the mosquito net was hung and used, they recorded it and the household where it was located. Each LLIN selected has been labeled to ensure proper identification during subsequent visits. The GPS coordinates of the household and the name of the head of the household, or of an adult person acting on behalf of the head (preferably his wife), were also recorded to facilitate monitoring. Marking and identified of the nets was done with a unique identifier (barcode). Their presence and physical condition in the household were assessed, as well as the characteristics of the households, their use, maintenance and behavior. The progress of the questionnaire at each follow-up was made possible through door-to-door visits. The questionnaire adapted to the needs of the 
study and used for the surveys was prepared by the research team of the Cotonou Entomological Research Center (CREC) which includes the following parts: general information; status of LLINs distributed, presence/physical absence of nets, rate of use, physical integrity, pattern of use of nets / frequency of use and washing practices. sub-samples of field nets were selected for insecticide efficacy tests and new replacement LLINs were given.

\subsection{Field Procedures}

Three teams made up of three investigators and a community relay carried out field activities per site under the supervision of a global site coordinator. Field activities were supervised by CREC staff. The selection of interviewers and supervisors has been carefully done so that they had a good knowledge of local languages, experience in conducting household surveys and above all, they were culturally acceptable. In addition, a list of household members and their property was obtained during the baseline and final surveys. If the households have moved inside the clusters, the new dwellings have been identified; if they have moved outside the cluster, they have been considered lost for monitoring. The baseline assessment was carried out six months after the campaign, data collection followed every 6 months.

\subsection{Data Management}

The data for our study was collected using tablets on which the Open Data Kit (ODK) software for the questionnaire was installed. The data from each field team was collected daily and directly uploaded to a secure database if the internet was available or collected on a local storage device by the coordinator until it could be transferred. After the surveys were completed, the datasets were transferred to version 14.2 of Stata (Stata, Texas 77845, USA) for further aggregation, consistency checks and preparation for analysis (Bhattarai A, et al., 2007).

\subsection{Data Analysis}

\subsubsection{Definition of Outcome}

The main objective of our results was the physical survival of the nets and was defined as the proportion of nets of the cohort received from the LLIN distribution campaign still in working condition (definition provided below) (WHO, 2011). For the determination of survival, two intermediate results were calculated as follows:

The net rate of loss (attrition) due to wear and tear which has been defined as the proportion of nets initially received which have been lost due to wear and tear (discarded, destroyed or used for other purposes) at the time of Evaluation. LLINs received but donated for use by others or stolen were excluded from the denominator.

The physical integrity of MILDs has been measured by the proportional hole index (pHI), as recommended by the WHO (WHO, 2013). The holes observed on the LLIN, were classified in four groups according to their sizes: size $1: 0.5-2 \mathrm{~cm}$, size $2: 2-10 \mathrm{~cm}$, size $3: 10-25 \mathrm{~cm}$ and size 4: more than $25 \mathrm{~cm}$ in diameter. The proportional $\mathrm{pHI}$ of each net was then calculated as suggested by the WHO (WHO, 2013). Each LLIN was then classified on the basis of the pHI, 
as "good", "damaged", "usable" or "torn" as follows (WHO, 2013):

Good: $\mathrm{pHI}<64$

Damaged: pHI 65-642

Torn: $\mathrm{pHI}>642$

Serviceable: $\mathrm{pHI} \leq 642$

The result of the median net survival was estimated as being the time in years until $50 \%$ of the LLINs originally distributed were no longer usable (WHO, 2013). After the final survey, the median net survival was calculated from the last two data points provided that they are both less than $85 \%$, using the following formula where tm is the median survival time, $\mathrm{t} 1$ and t 2 the first and second time points in years and $\mathrm{p} 1$ and $\mathrm{p} 2$ the proportion surviving the first and second time points respectively as a percentage (WHO, 2013).

\subsection{Assessment of Bio-efficacy}

\subsubsection{WHO Cone Test}

The evaluation of the chemical efficacy of LLINs was carried out using cone bioassays according to WHO guidelines, at the start and at each follow-up until the 30th month after the two distribution campaigns of the mosquito nets (WHO, 2019). At each follow-up, 50 LLINs of each type were randomly selected and removed from the different study areas for testing purpose. New nets have been given to homeowners to replace those removed for testing and holdings have not been included for bioassays in the future. Each of the removed LLINs was cut in 5 different places (the 4 sides plus the roof) into pieces $(30 \times 30 \mathrm{~cm})$ according to the WHOPES sampling plan (WHO, 2013). A sensitive laboratory strain (An. Gambiae Kisumu) was used to carry out the standard biological test in accordance with the recommendations of WHOPES (WHO, 2013). For this test, five females not engorged with blood, aged 2 to 5 days and belonging to this strain sensitive to pyrethroids were used. These mosquitoes were introduced simultaneously into the WHO cone and 10 cones were applied simultaneously to the mosquito net sample ( 2 per side). The exposure of mosquitoes to LLINs was three minutes. After the exposure, the females were grouped in batches of 5 in $200 \mathrm{ml}$ transparent plastic cups, covered with a net and kept at $28^{\circ} \mathrm{C} \pm 2{ }^{\circ} \mathrm{C}$ and a relative humidity of $80 \% \pm$ $10 \%$ with solution of $10 \%$ sugar. A total of 50 mosquitoes is therefore used per mosquito net. Each test day, four cones, each with 10 An. Gambiae Kisumu were exposed on an unimpregnated mosquito net as a negative control. The proportion of mosquitoes falling on the back was measured 60 minutes after exposure and mortality was assessed after 24 hours. If the mortality in the control was $>5 \%$ for a given day, the data were adjusted with the formula of Abbott (Abbott, 2004). If the mortality in the control was gieter than $>10 \%$, all the tests for that day were repeated. The standard protocol recommends using a mixed result, namely a mortality $\geq 80 \%$ or a KD $\geq 95 \%$ to consider a MIILD as effective. The number of mosquitoes that felt on their backs ("knock-down", KD) is recorded at 5-minute intervals for 60 minutes, which made possible the computing of the rate of KD at 60 minutes (KD 60). The percentage of mortality was calculated at 24 hours according to the immediate and 


\section{Macrothink}

deferred mortality defined in the WHO recommendations (WHO, 2013).

\subsection{Statistical Analysis}

To achieve the objectives of the study, we used descriptive analysis to highlight trends and levels of net use. The comparison of the average proportional hole index (pHI) of LLIN was made using the Kruskall Wallis test. The calculation of the proportions and their confidence interval was done using the binomial test. The analysis was performed using stata software and Microsoft Excel 2019 (MS Office 2019, USA). Baseline survival analysis was performed using Kaplan-Meier estimates of the survival function. The determinants of survival were studied using Cox proportional risk models. The tests were performed at the usual significance level of $5 \%$.

\section{Results}

\subsection{Risk Factors of Physical Durability}

Household-related factors known or suspected to be related to physical sustainability depended exclusively on the recall of survey respondents. Other key risk factor variables are presented in Table 2. Very few households store food in their bedroom, 9.4\%, 38.1\% and $21.5 \%$ respectively for PermaNet 2.0, DawaPlus 2.0 and Yorkool. However, it is believed that this could attract rodents to the rooms where the LLINs were located and increase, the risk of damage. The type of cooking in the bedrooms differed according to the sites and the LLINs (Table 1).

Table 1. Net-use environment at household

\begin{tabular}{|c|c|c|c|c|c|}
\hline \multicolumn{2}{|c|}{$\mathrm{N}_{\text {Differents Brands }}$ Months } & Baseline & 12 months & 18 months & 24 months \\
\hline \multicolumn{2}{|c|}{ PermaNet 2.0} & $\begin{array}{c}\mathrm{N}=434 \\
\%(95 \% \mathrm{CI})\end{array}$ & $\begin{array}{c}\mathrm{N}=398 \\
\%(95 \% \mathrm{CI})\end{array}$ & $\begin{array}{c}\mathrm{N}=288 \\
\%(95 \% \mathrm{CI})\end{array}$ & $\begin{array}{c}\mathrm{N}=143 \\
\%(95 \% \mathrm{CI})\end{array}$ \\
\hline \multirow[b]{2}{*}{$\begin{array}{l}\text { Location } \\
\text { of the } \\
\text { kitchen }\end{array}$} & $\begin{array}{l}\text { Outside }(383 ; \\
277 ; 261)\end{array}$ & $88.2(84.8-91.1)$ & $69.6(64.8-74.1)$ & $69.2(60.9-76.8)$ & $90.6(86.6-93.7)$ \\
\hline & $\begin{array}{l}\text { Inside } \\
121 ; 27)\end{array}$ & $11.8(8.9-15.1)$ & $30.4(29.5-33.4)$ & $30.7(23.3-39.0)$ & $9.4(8.3-11.5)$ \\
\hline \multirow{2}{*}{$\begin{array}{l}\text { Presence } \\
\text { of } \\
\text { electricity }\end{array}$} & $\begin{array}{l}\text { Yes }(246 ; \\
201 ; 162)\end{array}$ & $56.7(51.8-61.4)$ & $59.1(51.5-65.1)$ & $41.9(33.7-50.4)$ & $57.6(51.7-63.4)$ \\
\hline & $\begin{array}{l}\text { No } \quad(188 ; \\
139 ; 126)\end{array}$ & $43.3(38.6-48.1)$ & $40.9(40.9-52.5)$ & $58.0(49.5-66.2)$ & $42.4(40.2-48.1)$ \\
\hline \multirow{3}{*}{$\begin{array}{l}\text { Type of } \\
\text { energy } \\
\text { used in the } \\
\text { kitchen }\end{array}$} & $\begin{array}{l}\text { Wood }(312 ; \\
298 ; 258)\end{array}$ & $71.8(67.4-76.0)$ & $74.9(70.3-79.1)$ & $65.7(57.3-73.4)$ & $80.6(75.6-82.9)$ \\
\hline & $\begin{array}{l}\text { Charcoal } \quad(73 ; \\
41 ; 5)\end{array}$ & $16.8(13.4-20.7)$ & $10.3(7.4-13.7)$ & $25.2(18.3-33.1)$ & $0.3(0.0-0.5)$ \\
\hline & $\begin{array}{l}\text { Gas } \\
59 ; 55)\end{array}$ & $11.4(8.5-14.7)$ & $14.8(11.5-18.7)$ & $9.0(4.9-15.0)$ & $19.1(14.7-24.1)$ \\
\hline \multicolumn{2}{|c|}{ DawaPlus 2.0 } & $\begin{array}{c}\mathrm{N}=475 \\
\%(95 \% \mathrm{CI})\end{array}$ & $\begin{array}{c}\mathrm{N}=413 \\
\%(95 \% \mathrm{CI})\end{array}$ & $\begin{array}{c}\mathrm{N}=257 \\
\%(95 \% \mathrm{CI})\end{array}$ & $\begin{array}{c}\mathrm{N}=174 \\
\%(95 \% \mathrm{CI})\end{array}$ \\
\hline \multirow{3}{*}{$\begin{array}{l}\text { Location } \\
\text { of the } \\
\text { kitchen }\end{array}$} & $\begin{array}{l}\text { Outside }(449 ; \\
333 ; 159)\end{array}$ & $94.5(92.0-96.4)$ & $80.6(76.5-84.3)$ & $86.3(79.7-91.5)$ & $61.9(55.6-67.8)$ \\
\hline & $\begin{array}{l}\text { Inside } \quad(26 ; \\
80 ; 98) \quad\end{array}$ & $5.5(3.6-7.9)$ & $19.4(15.6-23.5)$ & $31.9(24.5-40.2)$ & $38.1(32.1-44.3)$ \\
\hline & $\begin{array}{l}\text { Yes }(150 ; \\
104 ; 118)\end{array}$ & $31.6(27.4-35.9)$ & $34.9(37.6-48.4)$ & $26.4(20.0-33.6)$ & $45.9(39.7-52.2)$ \\
\hline
\end{tabular}




\section{Il Macrothink}

Journal of Biology and Life Science

ISSN 2157-6076

2020, Vol. 11, No. 2

\begin{tabular}{|c|c|c|c|c|c|}
\hline $\begin{array}{l}\text { of } \\
\text { electricity }\end{array}$ & $\begin{array}{l}\text { No } 194 ; 139) \\
194 ;\end{array}$ & $68.4(64.0-72.6)$ & $65.1(59.6-70.4)$ & $72.9(65.7-79.4)$ & $54.1(47.7-60.3)$ \\
\hline \multirow{3}{*}{$\begin{array}{l}\text { Type of } \\
\text { energy } \\
\text { used in the } \\
\text { kitchen }\end{array}$} & $\begin{array}{l}\text { Wood }(391 ; \\
193 ; 155)\end{array}$ & $82.3(78.6-85.6)$ & $44.7(39.9-49.5)$ & $54.0(46.3-61.6)$ & $60.3(54.0-66.3)$ \\
\hline & $\begin{array}{l}\text { Charcoal }(55 \text {; } \\
103 ; 23)\end{array}$ & $11.6(8.8-14.8)$ & $23.7(19.8-28.0)$ & \multirow{2}{*}{$\begin{array}{c}36.2(29.0-43.8) \\
5.7(2.7-10.3)\end{array}$} & $9.0(5.7-13.1)$ \\
\hline & $\begin{array}{l}\text { Gas } \\
138 ; 79)\end{array}$ & $6.1(4.1-8.6)$ & $31.6(27.4-36.4)$ & & $30.7(25.1-36.7)$ \\
\hline \multicolumn{2}{|l|}{ Yorkool } & $\begin{array}{c}\mathrm{N}=480 \\
\%(\mathbf{9 5 \%} \mathrm{CI})\end{array}$ & $\begin{array}{c}\mathrm{N}=460 \\
\%(95 \% \mathrm{CI})\end{array}$ & $\begin{array}{c}\mathrm{N}=372 \\
\%(95 \% \mathrm{CI})\end{array}$ & $\begin{array}{c}\mathrm{N}=345 \\
\%(95 \% \mathrm{CI})\end{array}$ \\
\hline \multirow[b]{2}{*}{$\begin{array}{l}\text { Location } \\
\text { of the } \\
\text { kitchen }\end{array}$} & $\begin{array}{l}\text { Outside }(466 ; \\
419 ; 292)\end{array}$ & $97.0(95.1-98.4)$ & $91.1(88.1-93.5)$ & 61.7(56.4-66.9) & $78.5(73.9-82.7)$ \\
\hline & $\begin{array}{l}\text { Inside } \quad(14 ; \\
41 ; 80)\end{array}$ & $3.0(1.6-4.8)$ & $8.9(6.5-11.9)$ & $38.3(33.1-43.6)$ & $21.5(17.4-26.0)$ \\
\hline \multirow{2}{*}{$\begin{array}{l}\text { Presence } \\
\text { of } \\
\text { electricity }\end{array}$} & $\begin{array}{l}\text { Yes } \\
254 ; 207)\end{array}$ & $46.1(42.3-51.5)$ & $55.2(50.5-59.8)$ & $27.8(23.1-32.8)$ & $55.7(45.9-56.3)$ \\
\hline & $\begin{array}{l}\text { No } 206 ; 165) \\
206 ;\end{array}$ & $53.1(48.5-57.7)$ & $44.8(40.1-49.5)$ & $72.2(67.1-76.8)$ & $44.3(39.2-49.6)$ \\
\hline \multirow{3}{*}{$\begin{array}{l}\text { Type of } \\
\text { energy } \\
\text { used in the } \\
\text { kitchen }\end{array}$} & $\begin{array}{l}\text { Wood }(322 ; \\
236 ; 190)\end{array}$ & $67.0(62.7-71.3)$ & $51.3(46.6-55.9)$ & $37.9(32.8-43.3)$ & $51.1(45.8-56.3)$ \\
\hline & $\begin{array}{l}\text { Charcoal (145; } \\
184 ; 105)\end{array}$ & $30.2(26.1-34.5)$ & $40.0(35.4-44.6)$ & $38.26(33.1-43.6)$ & $28.2(23.7-33.1)$ \\
\hline & $\begin{array}{l}\text { Gas } \\
40 ; 77)\end{array}$ & $2.8(1.4-4.6)$ & $9.7(6.2-11.6)$ & $16.8(13.0-21.2)$ & 20.7 \\
\hline \multicolumn{2}{|l|}{ Total LLIN } & $\begin{array}{c}N=1389 \\
\%(95 \% \mathrm{CI})\end{array}$ & $\begin{array}{c}\mathrm{N}=1271 \\
\%(95 \% \mathrm{CI})\end{array}$ & $\begin{array}{c}\mathrm{N}=917 \\
\%(95 \% \mathrm{CI})\end{array}$ & $\begin{array}{c}\mathrm{N}=662 \\
\%(95 \% \mathrm{CI})\end{array}$ \\
\hline \multirow[b]{2}{*}{$\begin{array}{l}\text { Location } \\
\text { of the } \\
\text { kitchen }\end{array}$} & $\begin{array}{l}\text { Outside }(1298 ; \\
1029 ; 712)\end{array}$ & 93.4(92.0-94.7) & $80.9(78.7-83.1)$ & 66.3(62.6-69.9) & $77.6(74.8-80.3)$ \\
\hline & $\begin{array}{l}\text { Inside } \\
242 ; 205)\end{array}$ & $6.6(5.3-7.9)$ & 19.1(16.9-21.3) & $33.6(30.0-37.4)$ & $22.4(19.6-25.1)$ \\
\hline \multirow{2}{*}{$\begin{array}{l}\text { Presence } \\
\text { of } \\
\text { electricity }\end{array}$} & $\begin{array}{l}\text { Yes } \\
519 ; 307)\end{array}$ & $44.7(42.0-47.4)$ & $49.1(46.0-52.1)$ & $30.5(27.0-34.2)$ & $41.7(38.0-45.3)$ \\
\hline & $\begin{array}{l}\text { No } 539 ; 430) \\
539 ;\end{array}$ & $55.3(52.6-57.9)$ & $50.9(47.9-53.9)$ & 69.3(65.6-72.8) & $54.7(51.0-58.3)$ \\
\hline \multirow{3}{*}{$\begin{array}{l}\text { Type of } \\
\text { energy } \\
\text { used in the } \\
\text { kitchen }\end{array}$} & $\begin{array}{l}\text { Wood }(1025 ; \\
727 ; 603)\end{array}$ & 73.8(71.4-76.0) & $68.7(54.4-59.9)$ & $51.8(47.9-55.6)$ & $65.8(62.5-68.8)$ \\
\hline & $\begin{array}{l}\text { Charcoal (273; } \\
328 ; 133)\end{array}$ & $19.7(17.6-21.8)$ & $31.0(23.4-28.3)$ & $34.9(31.3-38.6)$ & $14.5(12.2-16.9)$ \\
\hline & $\begin{array}{l}\text { Gas } \quad(10 ; 8 ; \\
11)\end{array}$ & $0.7(0.3-1.3)$ & $3.0(0.1-0.8)$ & 13.3(10.7-16.1) & $19.7(17.2-22.4)$ \\
\hline
\end{tabular}

We found that the suspension of DawaPlus 2.0 LLINs increased over time, from $68 \%$ in the 6th month to $80.4 \%$ after 24 months. At the start of the study, $80 \%$ said they used washing detergent compared to $1.5 \%$ after 24 months. Over $84.2 \%$ said they had dried LLINs in the shade after washing. The same trend was noted at the level of PermaNet 2.0 and Yorkool with slight variation. 
Table 2. Net-use environment and washing of cohort nets from campaign

\begin{tabular}{|c|c|c|c|c|c|c|c|c|}
\hline \multicolumn{2}{|c|}{ Different Brands } & Baseline & \multicolumn{2}{|r|}{12 months } & \multicolumn{2}{|r|}{18 months } & \multicolumn{2}{|c|}{24 months } \\
\hline \multicolumn{2}{|c|}{ DawaPlus 2.0} & \multirow{2}{*}{$\begin{array}{r}\mathrm{N}=475 \%(95 \% \mathrm{CI}) \\
68.0(63.5-72.1)\end{array}$} & \multicolumn{2}{|c|}{$\mathrm{N}=298 \%(95 \% \mathrm{CI})$} & \multicolumn{2}{|c|}{$\mathrm{N}=176 \%(95 \% \mathrm{CI})$} & \multicolumn{2}{|c|}{$\mathrm{N}=133 \%(95 \% \mathrm{CI})$} \\
\hline \multirow{3}{*}{$\begin{array}{l}\text { Location } \\
\text { of LLIN }\end{array}$} & Hung & & 204 & $68.4(62.8-73.7)$ & 136 & $77.3(70.4-83.3)$ & 106 & 79.6(71.8-86.1) \\
\hline & Folded & $18.3(14.9-22.1)$ & 33 & $11.0(7.7-15.2)$ & 21 & $11.9(7.5-17.6)$ & 22 & $16.5(10.6-23.9)$ \\
\hline & Stored & $13.6(10.7-17.1)$ & 61 & $20.5(16.0-25.5)$ & 22 & $12.5(8.0-18.3)$ & 5 & $3.7(1.2-8.5)$ \\
\hline \multirow{3}{*}{$\begin{array}{c}\text { Sleeping } \\
\text { type }\end{array}$} & Bed & $23.7(20.0-27.8)$ & 104 & $34.9(29.5-40.6)$ & 58 & $32.9(26.0-40.4)$ & 60 & $45.1(36.47-53.9)$ \\
\hline & Mat & $72.0(67.7-75.9)$ & 174 & $58.4(52.6-64.0)$ & 112 & 63.6(56.0-70.7) & 70 & $52.6(43.8-61.3)$ \\
\hline & Banco & $4.2(2.5-6.4)$ & 20 & $6.7(4.1-10.2)$ & 6 & $3.4(1.2-7.2)$ & 3 & $2.2(0.4-6.4)$ \\
\hline \multirow[t]{2}{*}{$\begin{array}{c}\text { Use of } \\
\text { detergent }\end{array}$} & Yes & $80.0(76.1-83.5)$ & 53 & 17.7(13.6-22.6) & 44 & $\begin{array}{l}25.0 \\
(18.8-32.1)\end{array}$ & 2 & $1.5(0.2-5.3)$ \\
\hline & No & $20.0(16.4-23.8)$ & 245 & 82.2(77.4-86.4) & 132 & $75.0(67.9-81.2)$ & 131 & 98.5(94.6-99.8) \\
\hline \multirow{2}{*}{$\begin{array}{l}\text { Type of } \\
\text { Drying }\end{array}$} & $\begin{array}{l}\text { Out in } \\
\text { the sun }\end{array}$ & $81.3(77.6-84.5)$ & 111 & $37.2(31.7-43.0)$ & 116 & $65.9(58.4-72.9)$ & 21 & $15.7(10.0-23.1)$ \\
\hline & $\begin{array}{l}\text { Outside } \\
\text { in the } \\
\text { shade }\end{array}$ & $18.7(1$ & 187 & 62.7 & 60 & 34.1 & 112 & $-89.9)$ \\
\hline \multicolumn{2}{|c|}{ PermaNet 2.0} & $\mathrm{~N}=434 \%(95 \% \mathrm{CI})$ & \multicolumn{2}{|c|}{$\mathrm{N}=340 \%(95 \% \mathrm{CI})$} & \multicolumn{2}{|c|}{$\mathrm{N}=263 \%(95 \% \mathrm{CI})$} & \multicolumn{2}{|c|}{$\mathrm{N}=107 \%(95 \% \mathrm{CI})$} \\
\hline \multirow{4}{*}{$\begin{array}{l}\text { Location } \\
\text { of LLIN }\end{array}$} & Hung & $58.5(53.7-63.2)$ & 284 & $83.5(79.1-87.3)$ & 150 & $57.0(50.8-63.1)$ & 86 & $80.4(71.6-87.4)$ \\
\hline & Folded & $7.4(5.5-10.7)$ & 34 & $10.0(7.0-13.7)$ & 111 & $42.2(36.2-48.4)$ & 8 & $7.4(3.2-14.2)$ \\
\hline & Stored & $34.1(29.6-38.7)$ & 22 & $6.5(4.0-9.6)$ & 2 & $0.7(0.0-2.7)$ & 13 & $12.1(6.6-19.9)$ \\
\hline & Bed & $61.1(56.3-67.3)$ & 226 & $66.5(61.2-71.5)$ & 116 & $44.1(38.0-50.3)$ & 55 & $51.4(41.5-61.2)$ \\
\hline \multirow{2}{*}{$\begin{array}{c}\text { Sleeping } \\
\text { type } \\
200\end{array}$} & Mat & $27.6(23.4-32.1)$ & 96 & $28.2(23.5-33.3)$ & 145 & $55.1(48.9-61.2)$ & 49 & $45.8(36.1-55.7)$ \\
\hline & Banco & $11.3(8.4-14.6)$ & 18 & $5.3(3.2-8.2)$ & 2 & $0.7(0.0-2.7)$ & 3 & $2.8(0.5-7.9)$ \\
\hline \multirow{2}{*}{$\begin{array}{l}\text { Use of } \\
\text { detergent }\end{array}$} & Yes & $56.2(51.4-60.9)$ & 42 & $12.3(9.0-16.3)$ & 81 & $30.8(25.3-36.8)$ & 0 & $0.0(0.0-3.4)$ \\
\hline & & $43.7(39.1-48.5)$ & 298 & 87.6(83.6-90.9) & 182 & $69.2(63.2-74.7)$ & 107 & $100.0(96.6-100)$ \\
\hline \multirow{2}{*}{$\begin{array}{l}\text { Type of } \\
\text { Drying }\end{array}$} & $\begin{array}{l}\text { Out in } \\
\text { the sun }\end{array}$ & 99.5(98.3-99.9) & 153 & $45.0(39.6-50.5)$ & 201 & $76.4(70.8-81.4)$ & 44 & $41.1(31.7-51.0)$ \\
\hline & $\begin{array}{l}\text { Outside } \\
\text { in the } \\
\text { shade }\end{array}$ & $0.5(0.4-16.5)$ & 187 & $55.0(49.5-60.4)$ & 62 & $23.6(18.6-29.2)$ & 63 & $58.8(48.9-68.3)$ \\
\hline \multirow[t]{2}{*}{ Yorkool } & & $\mathrm{N}=480 \%(95 \% \mathrm{CI})$ & \multicolumn{2}{|c|}{$\mathrm{N}=420 \%(95 \% \mathrm{CI})$} & \multicolumn{2}{|c|}{$\mathrm{N}=295 \%(95 \% \mathrm{CI})$} & $\mathrm{N}=\mathbf{2 1 3}$ & $\%(95 \% \mathrm{CI})$ \\
\hline & Hung & $87.7(84.4-90.5)$ & 340 & $80.9(76.8-84.6)$ & 238 & $80.7(75.7-85.0)$ & 163 & $76.5(70.2-82.0)$ \\
\hline \multirow{2}{*}{$\begin{array}{l}\text { Location } \\
\text { of LLIN }\end{array}$} & Folded & $8.1(5.8-10.9)$ & 64 & 15.2(11.9-19.0) & 47 & $15.9(11.9-20.6)$ & 44 & $20.6(15.4-26.7)$ \\
\hline & $\begin{array}{l}\text { Stored } \\
\text { Bed }\end{array}$ & $\begin{array}{l}4.2(2.5-6.4) \\
63.12(58.6-67.4)\end{array}$ & $\begin{array}{l}16 \\
286\end{array}$ & $\begin{array}{l}3.8(2.2-6.1) \\
68.1(63.4-72.5)\end{array}$ & $\begin{array}{l}10 \\
212\end{array}$ & $\begin{array}{l}3.4(.6-6.1) \\
71.9(66.4-76.9)\end{array}$ & $\begin{array}{l}6 \\
168\end{array}$ & $\begin{array}{l}2.8(1.0-6.0) \\
78.8(72.7-84.1)\end{array}$ \\
\hline \multirow{4}{*}{$\begin{array}{l}\text { Sleeping } \\
\text { type } \\
200 \\
\text { Use of } \\
\text { detergent }\end{array}$} & Mat & $30.8(26.7-35.1)$ & 120 & $28.6(24.3-33.1)$ & 78 & $26.4(21.5-31.8)$ & 41 & $19.2(14.2-25.2)$ \\
\hline & Banco & ? & 245 & 58 & 5 & 1.6 & 4 & 1.8 \\
\hline & Yes & 9 & 1 & 4.5 & 113 & $38.3(32.7-44.1)$ & 5 & $2.3(0.7$ \\
\hline & No & $0.7(0.1-0.2)$ & 401 & 95.5(93.0-97.2) & 182 & $61.7(55.8-67.3)$ & 208 & 97.6(94.6-99.2) \\
\hline & Out in & $84.1(80.5-87.3)$ & 199 & $47.4(42.5-52.2)$ & 83 & $28.1(23.0-33.6)$ & 115 & $53.9(47.0-60.8)$ \\
\hline Drying & $\begin{array}{l}\text { Outside } \\
\text { in the } \\
\text { shade }\end{array}$ & $15.9(12.6-19.4)$ & 221 & $52.6(47.7-57.5)$ & 212 & $71.8(66.4-76.9)$ & 98 & $46.0(39.2-52.9)$ \\
\hline Total LLIN & & $\mathrm{N}=1389 \%(95 \% \mathrm{CI})$ & $\mathrm{N}=10$ & $8 \%(95 \% \mathrm{CI})$ & $\mathrm{N}=7$ & $\%(95 \% \mathrm{CI})$ & $\mathrm{N}=453$ & $(95 \% \mathrm{CI})$ \\
\hline & Hung & $76.2(73.8-78.5)$ & 828 & $78.3(75.6-80.7)$ & 524 & $71.1(67.7-74.3)$ & 355 & $78.4(74.3-82.1)$ \\
\hline & Folded & $12.0(10.3-13.9)$ & 131 & $12.4(10.4-14.5)$ & 179 & $24.3(21.2-27.5)$ & 74 & $16.3(13.0-20.0)$ \\
\hline
\end{tabular}




\begin{tabular}{lllllllll} 
& Stored & $11.8(10.0-13.6)$ & 99 & $9.3(7.6-11.2)$ & 34 & $3.2(2.0-4.8)$ & 24 & $5.3(3.4-7.8)$ \\
$\begin{array}{l}\text { Sleeping } \\
\text { type }\end{array}$ & Bed & $52.7(49.9-55.5)$ & 616 & $58.2(55.2-61.2)$ & 386 & $52.4(48.7-56.0)$ & 283 & $62.5(57.8-66.9)$ \\
$\mathbf{2 0 0}$ & Mat & $47.3(44.4-50.0)$ & 390 & $36.8(33.9-39.8)$ & 335 & $45.4(41.8-49.1)$ & 160 & $35.3(30.9-39.9)$ \\
& Banco & $0(--)$ & 99 & $9.3(7.6-11.3)$ & 16 & $2.7(1.2-3.5)$ & 10 & $2.2(1.0-4.0)$ \\
$\begin{array}{l}\text { Use of } \\
\text { detergent }\end{array}$ & Yes & $60.7(57.1-64.3)$ & 114 & $10.7(8.9-12.8)$ & 198 & $26.8(23.7-30.2)$ & 7 & $1.5(0.6-3.1)$ \\
& $\begin{array}{l}\text { No } \\
\text { Out in } \\
\text { the sun }\end{array}$ & $39.2(35.6-42.8)$ & 944 & $89.2(87.1-91.0)$ & 539 & $73.1(69.7-76.3)$ & 446 & $98.4(96.8-99.3)$ \\
$\begin{array}{l}\text { Type of } \\
\text { Drying }\end{array}$ & $\begin{array}{l}\text { Outside } \\
\text { in the } \\
\text { shade }\end{array}$ & $33.8(29.6-37-9)$ & 595 & $56.2(53.2-59.2)$ & 337 & $45.7(42.1-49.4)$ & 273 & $60.3(55.6-64.8)$ \\
\hline
\end{tabular}

\subsection{Frequency of Use of LLINs}

There is no significant difference in the use of mosquito nets every night between the district accross the monitoring periods. Unlike the DawaPlus ${ }^{\circledR}$ 2.0 LLINs where the use every night drop to $42 \%$ after 24 months of use, the PermaNet ${ }^{\circledR} 2.0$ and Yorkool® LLINs were used every night to more than $50 \%$. Less than $5 \%$ of households declared that they had never used the 3 brands of LLINs at all (figure 2).

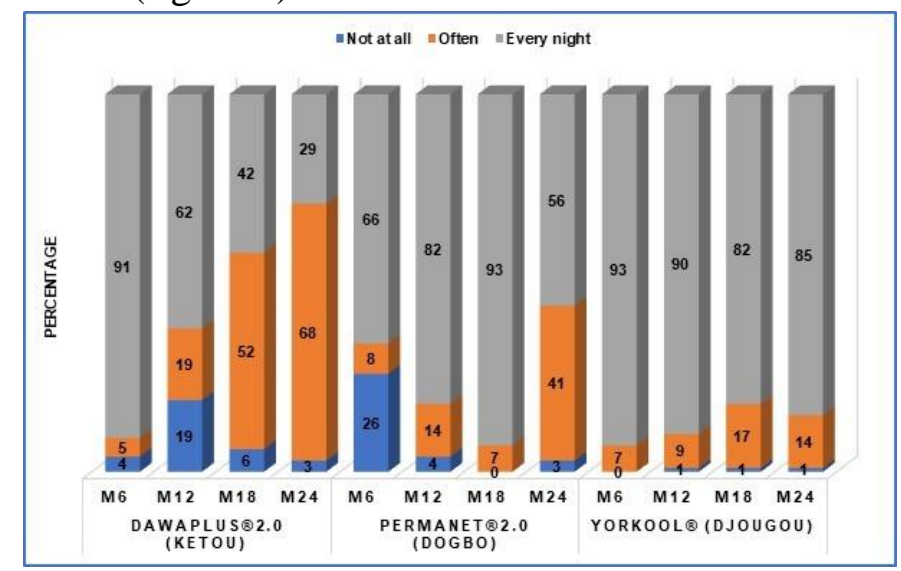

M6: 6 months, M12: 12 months, M18: 18 months, M24 : 24 months

Figure 2. Frequency of use of the campaign net

\subsection{Class of Person Using LLIN}

Use of nets among children has remained low over time in all districts (less than 20\%). No significant differences were noted between LLIN brands ( $p>0.05)$. The use of LLINs by both adults and children remained high between $39 \%$ and $95 \%$ at all three types of LLINs and study sites. Even these proportions have varied and declined over time, it must be noted that at all times, adults and children represented the highest proportion of those sleeping under nets in the study, with the number at 24 months being $41 \%$ in rural area versus $66 \%$ in urban areas $\left(\right.$ Yorkool $^{\circledR}$ ), $46.03 \%$ and $47 \%$ respectively in rural area vs urban area (PermaNet ${ }^{\circledR} 2.0$ ), $64 \%$ and $39.02 \%$ in rural area vs urban area (DawaPlus ${ }^{\circledR} 2.0$ ) (figure 3). Similarly, the use of LLINs by adults only remained fluctuating between $16 \%$ and $55 \%$ for all sites. 


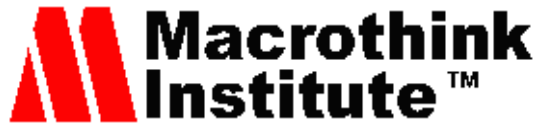
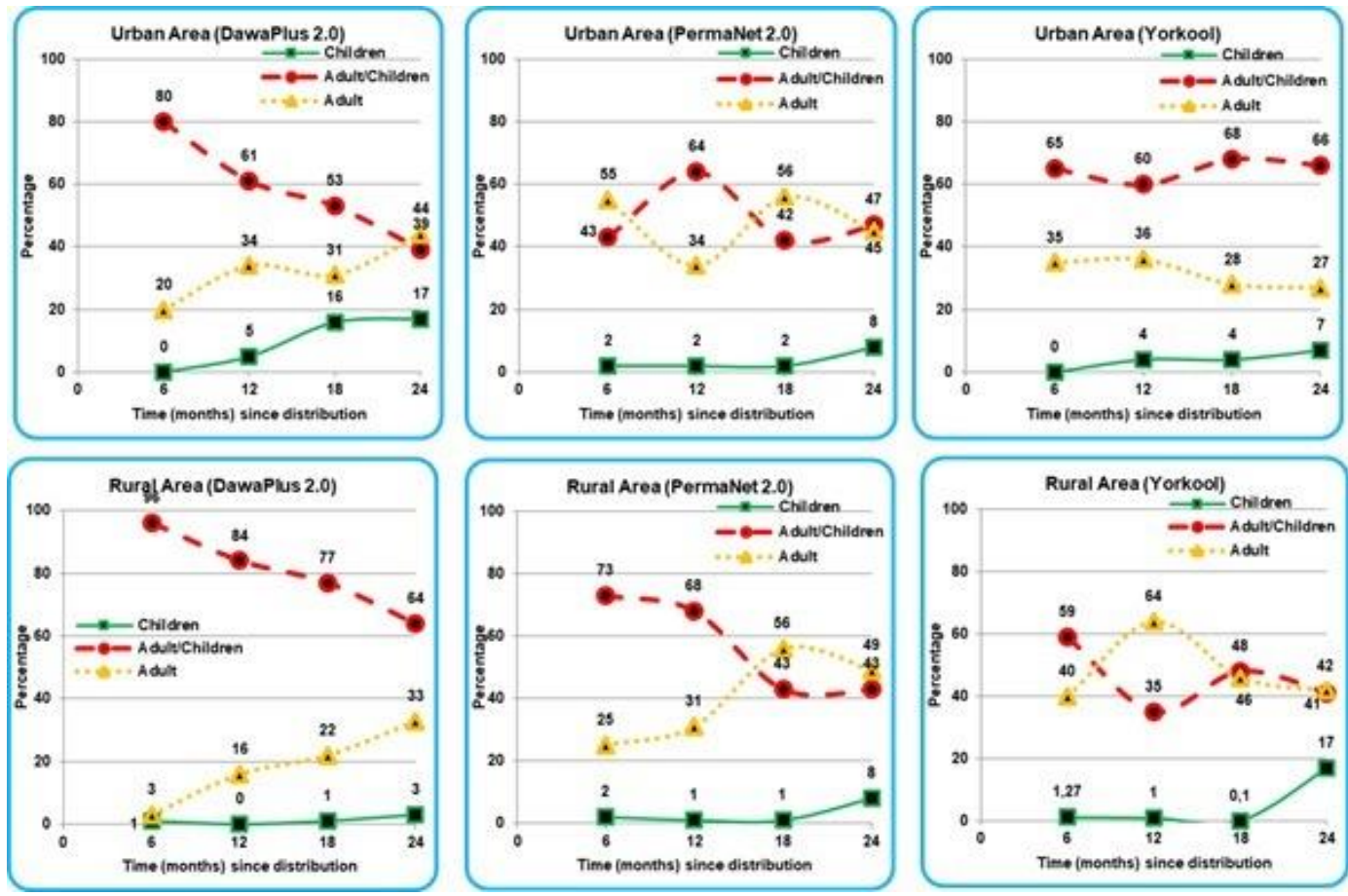

Figure 3. Classification of people using LLINs

\subsection{Net Loss}

Net attrition was significant during the study in all three LLINs, DawaPlus ${ }^{\circledR} 2.0$, PermaNet ${ }^{\circledR 2.0}$ and Yorkool ${ }^{\circledR}$. The proportion of households that still owned all the nets (DawaPlus ${ }^{\circledR 2.0)}$ received from the campaign was $26.6 \%$ while it was $21.4 \%$ and $42.6 \%$ respectively for PermaNet ${ }^{\circledR} 2.0$ and Yorkool ${ }^{\circledR}$ (Figure 4). The proportion of LLINs lost due to accidental tears did not exceed $7 \%$ in all communes except for the Yorkool@ LLIN where we observed $21.2 \%$ and $42.4 \%$ at 18 and 24 months of follow-up respectively. In addition, LLINs lost for other reasons did not represent more than $7 \%$ (Figure 5).

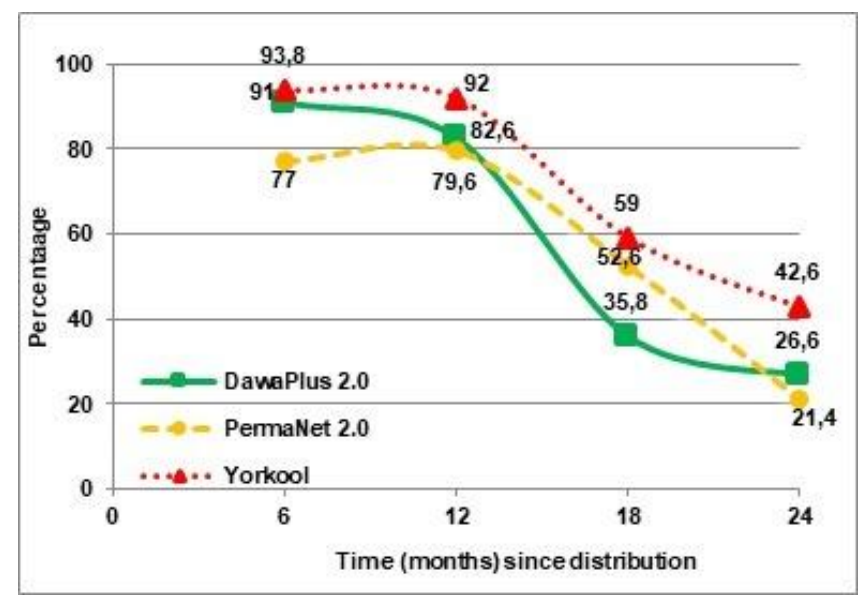

Figure 4. Proportion of household who were still in possession of the nets they received from the campaign 


\section{Ml Macrothink}

Secondly, the moved was the main reason for loss. This practice was observed and more pronounced mainly during the 18th and 24th months in Ketou, 52.2\%, 57.6\% against 38.2\%, $45.8 \%, 22 \%$ and $26.8 \%$ respectively in Dogbo and Djougou during the same period. The proportion of LLINs lost due to accidental tears did not exceed $7 \%$ in all the communes except for the LLIN Yorkool where we observed $21.2 \%$ and $42.4 \%$ respectively at 18 and 24 months of follow-up. LLINs lost for other reasons also did not exceed 7\% (Figure 5).
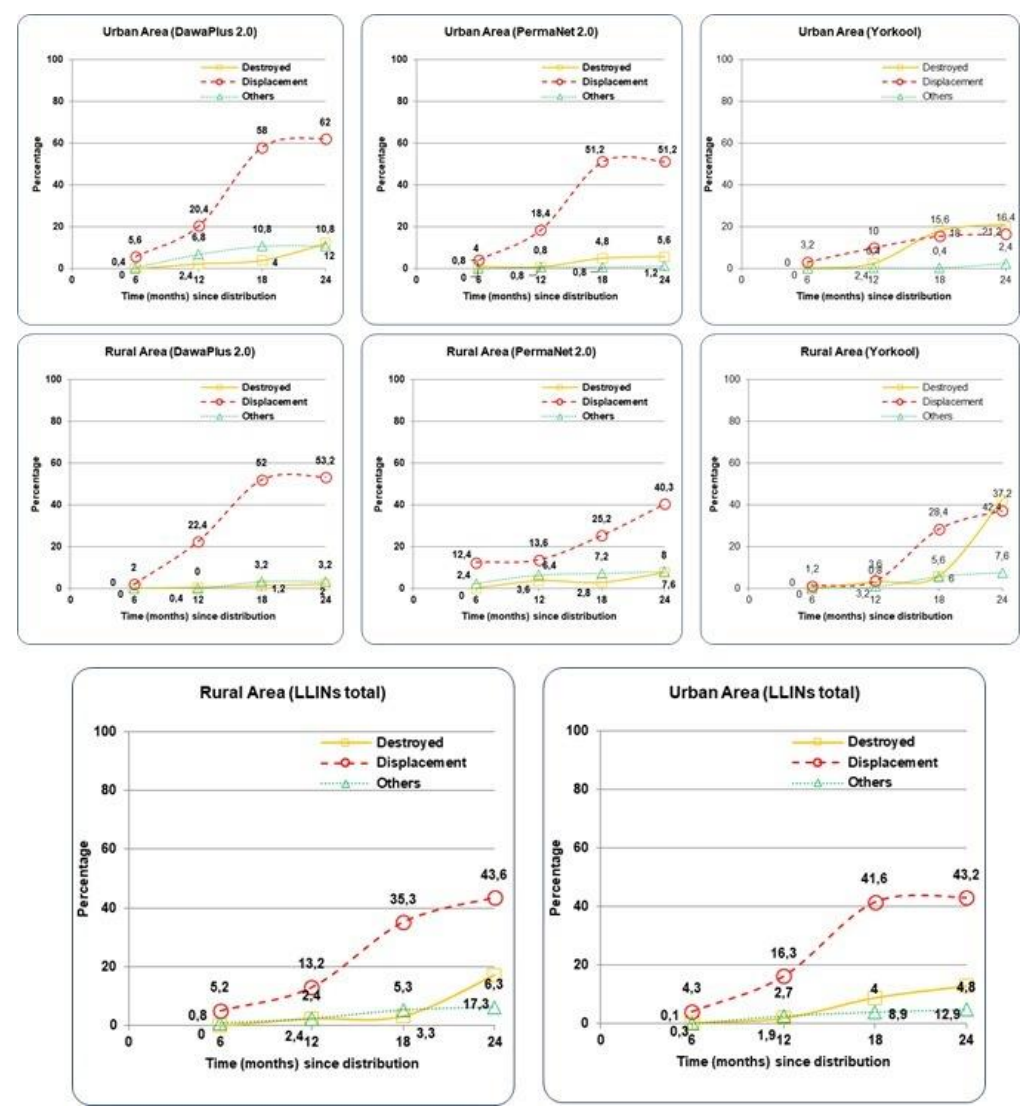

Figure 5. Main reasons for the loss of LLINs by brand and by area

\subsection{Physical Damaged and pHI Indicator}

In the 24-month survey, $21.7 \%$ of nets (all brands) compared to $1.9 \%$ at six months were holed, and the level of damage was very similar for all three LLIN brands, based on the median hole index $(\mathrm{p}>0.05)$. The proportion of LLINs in good condition and usable decreased slightly over time, while the proportion of damaged and torn LLINs increased. Simple Tears were more prevalent and ranged from $1.7 \%$ to $16.6 \%$ in the different surveys, but differed between sites (table 3 ). 
Table 3. Integrity of campaign nets present in households

\begin{tabular}{|c|c|c|c|c|c|c|c|c|c|}
\hline \multirow{3}{*}{\multicolumn{2}{|c|}{$\begin{array}{l}\text { Different Brands } \\
\text { DawaPlus } 2.0 \\
\text { Net has any hole }(95 ; 80)\end{array}$}} & \multirow{3}{*}{$\begin{array}{l}\text { Baselin } \\
\mathbf{N}=475 \\
14\end{array}$} & \multirow{3}{*}{$\begin{array}{l}\%(95 \% \mathrm{CI}) \\
2.9(1.6-4.9)\end{array}$} & \multirow{2}{*}{\multicolumn{2}{|c|}{$\begin{array}{l}12 \text { months } \\
\mathrm{N}=413 \%(95 \% \mathrm{CI})\end{array}$}} & \multicolumn{2}{|c|}{18 months } & \multicolumn{2}{|c|}{24 months } \\
\hline & & & & & & \multicolumn{2}{|c|}{$\mathrm{N}=257 \%(95 \% \mathrm{CI})$} & \multicolumn{2}{|c|}{$174 \%(95 \% \mathrm{CI})$} \\
\hline & & & & 38 & $9.2(6.6-12.4)$ & 47 & $18.2(13.7-23.5)$ & 68 & $39.0(31.8-46.7)$ \\
\hline \multirow{4}{*}{$\begin{array}{l}\text { Physical } \\
\text { condition } \\
(\mathrm{pHI})\end{array}$} & $\begin{array}{l}\text { Good } \quad(0-64) \\
(168)\end{array}$ & 462 & $97.3(95.4-98.5)$ & 395 & $95.6(93.2-97.4)$ & 223 & $86.7(82.0-90.6)$ & 127 & $72.9(73.6-81.7)$ \\
\hline & $\begin{array}{l}\text { Damaged } \\
(65-642)(32)\end{array}$ & 10 & $2.1(1.0-3.8)$ & 14 & $3.3(1.8-5.6)$ & 20 & $7.7(4.8-11.7)$ & 29 & $16.6(11.1-23.0)$ \\
\hline & Torn $(>642)$ & 3 & $0.6(0.1-1.8)$ & 4 & $0.9(0.2-2.4)$ & 14 & $5.4(3.0-8.9)$ & 18 & $10.3(6.2-15.8)$ \\
\hline & $\begin{array}{l}\text { Serviceable } \\
(0-642)\end{array}$ & 472 & $99.4(98.5-99.8)$ & 409 & $99.0(97.5-99.7)$ & 243 & $94.5(91.0-96.9)$ & 156 & 89.6(84.1-93.7) \\
\hline \multicolumn{2}{|c|}{ Median pHI if any hole (IQR) } & & $578(196-611)$ & & $48(7-284)$ & & $221(52-707)$ & & $219.5(49-700)$ \\
\hline \multicolumn{2}{|c|}{ PermaNet 2} & \multicolumn{2}{|c|}{$\mathrm{N}=434 \%(95 \% \mathrm{CI})$} & \multicolumn{2}{|c|}{$\mathrm{N}=398 \%(95 \% \mathrm{CI})$} & \multicolumn{2}{|c|}{$\mathrm{N}=112 \%(95 \% \mathrm{CI})$} & \multicolumn{2}{|c|}{$\mathrm{N}=143 \%(95 \% \mathrm{CI})$} \\
\hline \multicolumn{2}{|c|}{ Net has any hole $(109 ; 74)$} & 8 & $1.8(0.7-3.5)$ & 24 & $6.0(3.9-8.8)$ & 56 & $50(40.4-59.5)$ & 28 & 19.5(13.4-27.0) \\
\hline \multirow{4}{*}{$\begin{array}{l}\text { Physical } \\
\text { condition } \\
\text { (pHI) }\end{array}$} & $\begin{array}{l}\text { Good } \quad(0-64) \\
(182)\end{array}$ & 427 & $98.4(96.7-99.3)$ & 389 & $97.7(95.7-98.9)$ & 105 & $93.7(87.5-97.4)$ & 125 & 87.4(80.8-92.4) \\
\hline & $\begin{array}{l}\text { Damaged } \\
(65-642)(54)\end{array}$ & 4 & $0.9(0.2-2.3)$ & 7 & $1.7(0.7-3.6)$ & 6 & $8.3(1.9-11.2)$ & 14 & $9.7(5.4-15.8)$ \\
\hline & Torn $(>642)$ & 3 & $0.6(0.1-2.0)$ & 2 & $0.5(0.0-1.8)$ & 1 & $0.8(0.0-4.8)$ & 4 & $2.7(0.7-7.0)$ \\
\hline & $\begin{array}{l}\text { Serviceable } \\
(0-642)\end{array}$ & 431 & 99.3(97.9-99.8) & 396 & & 111 & 99.1(95.1-99.9) & 139 & 97.2(92.9-99.2) \\
\hline \multicolumn{2}{|c|}{ Median pHI if any hole (IQR) } & & $578(398.5-767)$ & & $42.5(14.5-215)$ & & $23(1-196)$ & & $243(46-463.5)$ \\
\hline \multicolumn{2}{|c|}{ Yorkool } & \multicolumn{2}{|c|}{$\mathrm{N}=480 \%(95 \% \mathrm{CI})$} & \multicolumn{2}{|c|}{$\mathrm{N}=460 \%(95 \% \mathrm{CI})$} & \multicolumn{2}{|c|}{$\mathrm{N}=295 \%(95 \% \mathrm{CI})$} & \multicolumn{2}{|c|}{$\mathrm{N}=345 \%(95 \% \mathrm{CI})$} \\
\hline \multicolumn{2}{|c|}{ Net has any hole (82;63) } & 5 & $1.0(0.3-2.4)$ & 25 & $5.4(3.5-7.9)$ & 36 & $12.2(8.6-16.5)$ & 48 & 13.9(10.4-18.0) \\
\hline \multirow{4}{*}{$\begin{array}{l}\text { Physical } \\
\text { condition } \\
\text { (pHI) }\end{array}$} & $\begin{array}{l}\text { Good } \quad(0-64) \\
(152)\end{array}$ & 476 & $99.1(97.8-99.7)$ & 448 & $97.3(95.5-98.6)$ & 284 & $96.2(93.4-98.1)$ & 318 & $92.1(88.8-94.7)$ \\
\hline & $\begin{array}{l}\text { Damaged } \\
(65-642)\end{array}$ & 1 & $0.2(0.0-1.1)$ & 10 & $2.1(1.0-3.9)$ & 7 & $2.3(0.9-4.8)$ & 21 & $6.0(3.8-9.1)$ \\
\hline & Torn $(>642)$ & 3 & $0.6(0.1-1.8)$ & 2 & $0.4(0.0-1.6)$ & 4 & $1.3(0.3-3.4)$ & 6 & $1.7(6.4-3.7)$ \\
\hline & $\begin{array}{l}\text { Serviceable } \\
(0-642)\end{array}$ & 477 & 99.3(98.1-99.8) & 458 & 99.5(98.4-99.9) & 291 & $98.6(96.6-99.6)$ & 339 & $98.3(96.2-99.3)$ \\
\hline \multicolumn{2}{|c|}{ Median pHI if any hole (IQR) } & & $843(392-854)$ & & $48(23-219)$ & & $24.5(16.5-145)$ & & $74.5(25-323.5)$ \\
\hline \multicolumn{2}{|c|}{ Total LLIN } & \multicolumn{2}{|c|}{$\mathrm{N}=1389 \%(95 \% \mathrm{CI})$} & \multicolumn{2}{|c|}{$\mathrm{N}=1271 \%(95 \% \mathrm{CI})$} & \multicolumn{2}{|c|}{$\mathrm{N}=664 \%(95 \% \mathrm{CI})$} & $\mathrm{N}=6 \mathrm{C}$ & $2 \%(95 \% \mathrm{CI})$ \\
\hline Net has an & $(286 ; 217)$ & 27 & $1.9(1.3-2.8)$ & 87 & $6.8(5.5-8.3)$ & 139 & $20.9(17.8-24.2)$ & 144 & 21.7(18.6-25.0) \\
\hline & Good $(0-64)$ & 1365 & 98.3(97.4-98.8) & 1232 & $9.6(8.1-11.4)$ & 612 & $92.1(89.8-94.0)$ & 570 & $86.1(83.2-88.6)$ \\
\hline Physical & $\begin{array}{l}\text { Damaged } \\
(65-642)\end{array}$ & 15 & $1.0(0.6-1.7)$ & 31 & $2.4(1.6-3.4)$ & 33 & $4.9(3.4-6.9)$ & 64 & $9(7.5-12.1)$ \\
\hline condition & Torn (> 642) & 9 & $0.6(0.2-1.2)$ & 8 & $0.6(0.2-1.2)$ & 19 & $2.8(1.7-4.4)$ & 28 & $4.2(2.8-6.0)$ \\
\hline (pHI) & $\begin{array}{l}\text { Serviceable } \\
(0-642)\end{array}$ & 1380 & 99.3(98.7-99.7) & 1263 & $99.4(98.7-99.7)$ & 645 & $97.1(95.5-98.3)$ & 634 & $95.7(93.9-97.2)$ \\
\hline Median pl & ny hole (IQR) & & $578(219-843)$ & & $46(23-225)$ & & $69(23-465)$ & & $196(46-524.5)$ \\
\hline
\end{tabular}

CI: Confidence interval

\subsection{Survival in Serviceable Condition}

After 12 months of follow-up, the survival rate of DawaPlus®2.0 nets was 1 point lower than that of PermaNet ${ }^{\circledR 2} .0$ and 1.2 points lower than that of Yorkool. The difference was 1.4 points for DawaPlus 2.0 and Yorkool compared to PermaNet®2.0 at 24 months (figure 6). 


\section{Macrothink}

The survival at Ketou and Djougou was lower when the dataset was considered in a Kaplan-Meier survival function using an intention to treat approach ( $\mathrm{p}<0.0001)$.

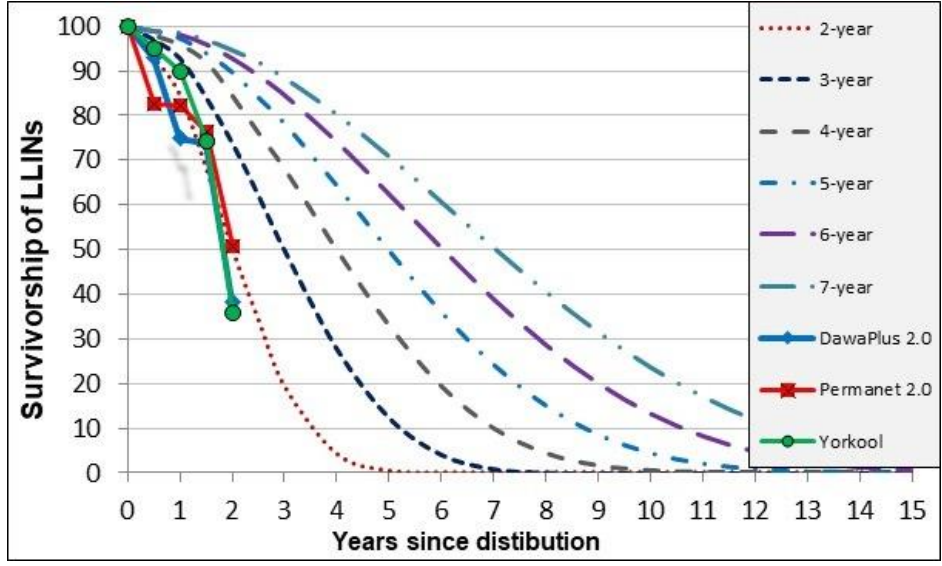

Figure 6. Survivorship of the three types of LLINs at baseline, 12, 18 and 24 months following the NetCalc model

\subsection{Determinants of Physical Durability}

Cox proportional hazard models that examine the determinants of physical survival are presented in Table 5. The risk of not surviving increased when the LLIN was dried in the sun, or when the type of coating was the mat and the LLIN was constantly hung (Hazard Ratio adjusted aHR) $0.25, \mathrm{p} \leq 0.052$ ).

After 24 months of study, a significant difference was noted between DawaPlus 2.0 and the other two LLINs (aHR 0.25, $\mathrm{p}=0.000$ ). The observation was the same when the use was in the presence of the mat (aHR 0.11, p = 0.006) or the bed (aHR 0.14, p =0.01) as a type of bedding. In addition, the fact that the LLINs were still suspended testified to their actual use, which means that, over time, in surveys, the number of LLINs found in a folded or row position increases, showing a significant effect with a Hazard Ratio (aHR) adjusted from 2.76 and 5.75 .

Table 4. Determinants of physical durability (risk of failure to survive in serviceable condition) from Cox proportional hazard models

\begin{tabular}{|c|c|c|c|}
\hline Variable & Adjusted hazard ratio (HR) & $95 \% \mathrm{CI}$ & P-value \\
\hline \multicolumn{4}{|c|}{$\begin{array}{l}\text { At household level ; } \mathrm{N}=1389 \text { obs } \\
\text { After } 6 \text { months }\end{array}$} \\
\hline \multicolumn{4}{|l|}{ Sites/Type of LLIN } \\
\hline DawaPlus & -- & & \\
\hline PermaNet 2.0 & 0.00 & & 0.000 \\
\hline Yorkool & 1.00 & & \\
\hline \multicolumn{4}{|c|}{ Number of people sleeping under LLIN } \\
\hline None & 1.00 & & \\
\hline $1-2$ & 0.20 & $0.3-1.2$ & 0.075 \\
\hline 3 or more & 1.79 & $1.5-2.1$ & 0.641 \\
\hline \multicolumn{4}{|l|}{ Drying location } \\
\hline Outside in the shade & 1.00 & & \\
\hline Out in the sun & 0.00 & & 0.000 \\
\hline \multicolumn{4}{|l|}{ User detergent } \\
\hline Yes & 0.43 & $0.1-2.5$ & 0.34 \\
\hline No & 1.00 & & \\
\hline \multicolumn{4}{|l|}{ Sleeping Type } \\
\hline Matt & 0.00 & & 0.000 \\
\hline
\end{tabular}


Bamboo

Storage state

Hung

Folded

Stored

Users of LLIN

Children

Adults

Children \& Adults

At household level ; N= 662 obs

After 24 months

Sites/Type of Brand

$--$
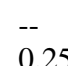

0.25

1.00

1.00

0.59
$-$

$0.1-1.0$

0.052

0.1-4.9
DawaPlus

PermaNet 2.0

Yorkool

Number of people sleeping under LLIN

None

1-2

3 or more

Drying location

Outside in the shade

Out in the sun

User detergent

Yes

No

Sleeping Type

Matt

Bed

Bamboo

Storage state

Hung

Folded

Stored

\section{1}

.25

1.00

.37

.44

1

93

\section{1}

0.83

0.11

0.14

1.0

1

2.76

5.75

Users of LLIN

Children

Adults

Children \& Adults

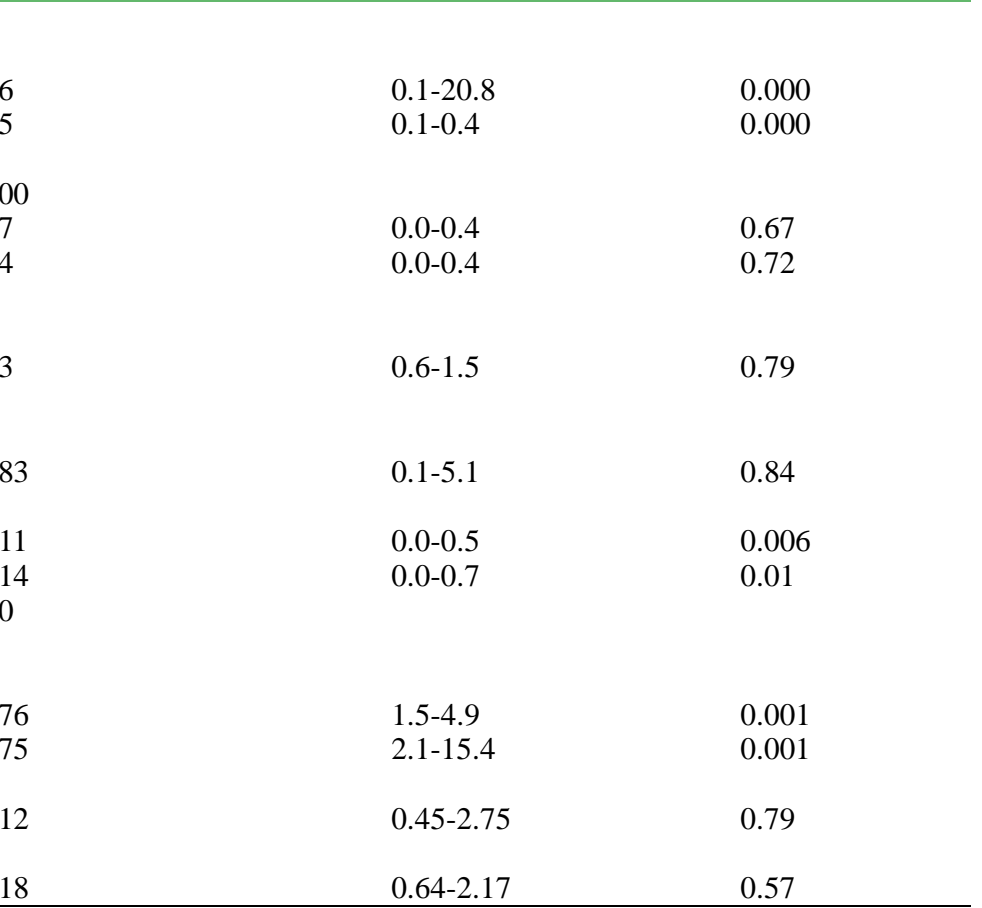

Obs: observations

\subsection{Insecticidal Effectiveness}

The objective of sampling 50 field nets at each site for biological tests was reached at all times and on the three sites. Concerning the PermaNet ${ }^{\circledR} 2.0$ LLIN, the proportion of mosquito that felt on the back (knock-down) after 60 minutes slightly decreased at all measurement points, as well as the mortality after 24 hours over time, going from a median of $96.3 \%$ to $83.3 \%$ during the assessment of the 24 th month. For Yorkool ${ }^{\circledR}$ and DawaPlus ${ }^{\circledR} 2.0$ treated with deltamethrin, the mortality rates of pyrethroid-sensitive vectors were similar. There was no evidence that the campaign LLINs sampled at 12 and 24 months outside the study cohort differed from the LLINs in the cohort in terms of suspension, use and washing

Table 5. Results from bio-assays

\begin{tabular}{llllll}
\hline Variable & Periods & & & \\
\cline { 2 - 5 } & Baseline & 6 months & 12 months & 18 months & 24 months \\
\hline PermaNet 2.0 & & & & \\
KD 60min & $98.5 \%$ & & & & \\
Mean (CI-95\%) & \begin{tabular}{l} 
(97.6-99.3) \\
\multicolumn{1}{c}{ Median IQR }
\end{tabular} & $98.9 \%(98-99.7)$ & $97.9 \%(96.7-99)$ & $\begin{array}{l}86.9 \\
(84.4-89.4)\end{array}$ & $\begin{array}{l}84.6 \% \\
(81.8-87.3)\end{array}$
\end{tabular}




\section{Ml Macrothink}

\begin{tabular}{|c|c|c|c|c|c|}
\hline & $\begin{array}{l}100 \% \\
(100-97.6)\end{array}$ & $\begin{array}{l}100 \% \\
(100-98.5)\end{array}$ & $\begin{array}{l}100 \% \\
(100-96.9)\end{array}$ & $\begin{array}{l}85.9 \% \\
(94.5-80.6)\end{array}$ & $\begin{array}{l}82.1 \% \\
(93.2-78)\end{array}$ \\
\hline $\begin{array}{l}\text { Mortality 24h } \\
\text { Mean (CI-95\%) }\end{array}$ & $\begin{array}{l}95.6 \% \\
(94.5-96.7)\end{array}$ & $\begin{array}{l}94.2 \% \\
(93.1-95.4)\end{array}$ & $92 \%(89.7-94.3)$ & $\begin{array}{l}82.9 \% \\
(80.7-85)\end{array}$ & $\begin{array}{l}82.2 \% \\
(80.2-84.2)\end{array}$ \\
\hline Median IQR & $\begin{array}{l}96.3 \% \\
(98.1-92.7)\end{array}$ & $\begin{array}{l}94.4 \% \\
(96.6-91.8)\end{array}$ & $\begin{array}{l}93.8 \% \\
(100-87.2)\end{array}$ & $\begin{array}{l}84 \% \\
(87.2-76.9)\end{array}$ & $\begin{array}{l}83.3 \% \\
(87.8-75.3)\end{array}$ \\
\hline \multicolumn{6}{|l|}{ Yorkool } \\
\hline $\begin{array}{l}\text { KD 60min } \\
\text { Mean }(\text { CI-95\%) } \\
\text { Median IQR }\end{array}$ & $\begin{array}{l}98.1 \% \\
(96.8-99.4) \\
100 \% \\
(100-97.4)\end{array}$ & $\begin{array}{l}96.5 \% \\
(95.2-97.9) \\
97.7 \% \\
(100-95.2)\end{array}$ & $\begin{array}{l}97.1 \% \\
(96.5-97.8) \\
97.1 \% \\
(100-95.6)\end{array}$ & $\begin{array}{l}73.5 \% \\
(68.5-78.6) \\
74.2 \% \\
(86.8-62)\end{array}$ & $\begin{array}{l}82.5 \% \\
(78.3-86.7) \\
82.2 \% \\
(95.2-73.2)\end{array}$ \\
\hline $\begin{array}{l}\text { Mortality } \mathbf{2 4 h} \\
\text { Mean (CI-95\%) }\end{array}$ & $93.1 \%(91-95.2)$ & $\begin{array}{l}95.6 \% \\
(94.3-96.8)\end{array}$ & $83 \%(81.9-84.1)$ & $\begin{array}{l}94 \% \\
(91.8-96.2)\end{array}$ & $\begin{array}{l}88.9 \% \\
(86.7-91)\end{array}$ \\
\hline Median IQR & $95.7 \%(98-91.2)$ & $\begin{array}{l}97.5 \% \\
(97.8-94.4)\end{array}$ & $82.2 \%(86-79.4)$ & $\begin{array}{l}99.3 \% \\
(100-89.8)\end{array}$ & $\begin{array}{l}90.4 \% \\
(94.6-85.3)\end{array}$ \\
\hline \multicolumn{6}{|l|}{ DawaPlus 2.0 } \\
\hline $\begin{array}{l}\text { KD 60min } \\
\text { Mean (CI-95\%) }\end{array}$ & $\begin{array}{l}99.1 \% \\
(98.6-99.6) \\
100 \% \\
(100-97.9)\end{array}$ & $\begin{array}{l}99.3 \% \\
(98.6-100) \\
100 \%(100-100)\end{array}$ & $\begin{array}{l}92.6 \%(91.2-94) \\
93.1 \% \\
(96.9-89.6)\end{array}$ & $\begin{array}{l}91.2 \% \\
(89.8-92.5) \\
89.8 \%(94-88)\end{array}$ & $\begin{array}{l}85.5 \% \\
(83.7-87.4) \\
84.1 \% \\
(90.2-80.4)\end{array}$ \\
\hline $\begin{array}{l}\text { Mortality } 24 \mathbf{4 h} \\
\text { Mean (CI-95\%) }\end{array}$ & $96 \%(95.1-96.9)$ & $98.1 \%(97.2-99)$ & $97.9 \%(97-98.7)$ & $\begin{array}{l}89.9 \% \\
(88.6-91.3)\end{array}$ & $\begin{array}{l}91.4 \% \\
(89-93.8)\end{array}$ \\
\hline Median IQR & $95.5 \%(98-93.3)$ & $\begin{array}{l}100 \% \\
(100-97.2)\end{array}$ & $\begin{array}{l}98.4 \% \\
(100-96.5)\end{array}$ & $90.5 \%(93-89)$ & $\begin{array}{l}93.4 \% \\
(98.3-85.7)\end{array}$ \\
\hline
\end{tabular}

CI: Confidence interval

\section{Discussion}

At the end of our study, the second of its kind which evaluated several LLINs under operational conditions in our country, by comparing the physical and insecticide durability of three brands of LLINs, DawaPlus ${ }^{\circledR 2.0,} 150$ denier, PermaNet ${ }^{\circledR} 2.0100$ denier and Yorkool ${ }^{\circledR}$, the last 100, all based on polyester treated with deltamethrin, over a period of 2 years, it showed us that physical survival in working condition was lower for the DawaPlus ${ }^{2} .0$ and Yorkool@ zones after 24 months as Yorkool®. This difference was $1 \%$ points at 6 and 12 months of follow-up and increased to $1.4 \%$ points after the evaluation of the 24th month after distribution with a survival in working condition of $38.2 \%$ for Ketou (DawaPlus®2.0), 50.9\% for Dogbo (PermaNet ${ }^{\circledR 2.0}$ ), and 35.8\% for Djougou (Yorkool®). The Kaplan-Meier survival function not adjusted by zone/brand showed tangible evidence of a significant difference ( $p<0.001)$. This study was designed to assess the comparison in different environments to identify the effects of factors other than the brand of LLINs. The three municipalities selected at random, one in the north of the country, the other on a plateau and the last in the south of the country were, in fact, very different in terms of their climatic, demographic and socio-economic characteristics. In addition, one of the six potential risk factors for physical sustainability measured at the household and mosquito net level had no impact with some differences between the zones (the number of sleepers per LLIN, was found in proportional risk models de Cox, have no influence on physical survival in this context. There therefore remain the factors that could have influenced the results of physical sustainability between the three zones. These are the detergent used for washing, drying the nets outside in the sun, the type of bedding and the user of LLINs. In our study, we noted a difference between the Monitoring Zones although all the LLINs in study were made of polyester. This makes it possible to deduce that, taking into account the existing differences between the zones, the survival DawaPlus ${ }^{2} .0$ and Yorkool@ 
was significantly lower than that of PermaNet ${ }^{2} 2.0$. The three brands of LLINs have been compared to other large sustainability studies conducted in different African countries. A study conducted in Zanzibar and published in 2020 showed a survival of $75.8 \%$ for PermaNet ${ }^{\circledR 2} .0$ compared under conditions similar to Olyset巴 after 2 years of follow-up (Haji, K. A., et al., 2020). This result, similar to that obtained in India for the same brand of LLIN (74.8 after 30 months) is much higher than the 50.9\% survival of PermaNet®2.0 in our study (Sudhansu Sekhar Sahu, et al., 2020). On the other hand, another study carried out in Congo, still published in 2020 and which compared DuraNet ${ }^{\circledR}$ to DawaPlus ${ }^{\circledR} 2.0$ found a survival of $33.2 \%$ for the LLIN DawaPlus ${ }^{\circledR} 2.0$ after 2 years, a result similar to our for the same type of LLIN after 2 years of follow-up (38.2\%) (Mansiangi, P, et al., 2020).

It was observed in the current study that approximately $21 \%$ of LLINs (all types) had holes after 2 years of field use and that only $4.2 \%$ of LLINs found present at this follow-up time were still usable. The recent study carried out in India revealed a presence of a hole in the proportion of $60 \%$ and that nearly $35 \%$ of LLINs were no longer usable (Sudhansu Sekhar Sahu, et al., 2020). In Chad where $39 \%$ of the PermaNet®2.0 or Interceptor ${ }^{\circledR}$ LLINs followed from 1 to 2 years after their distribution in 2007-2008 were no longer usable (Allan $\mathrm{R}$, et al., 2012). However, in this case, the polyester LLIN had a thread of 75 deniers and not 100 deniers as in this study or the other studies cited above. What is remarkable is that we noted around $80 \%$ loss at the LLIN level, the main reason for which was displacement $43.6 \%$ in rural areas against $43.2 \%$ in urban areas. This clearly indicates that it was not the quality of the LLIN tissue that was poor and did not meet the WHO criteria, i.e. a net life span of 3 years as planned by the manufacturers, but probably this behavior of the community and improper handling of LLINs, hence wear and tear as the second reason for the loss of LLINs. In the Indian study, the main cause of wear $(75.8 \%)$ reported was the damage of the nets due to wear (real wear). Several other studies have shown that most LLINs were torn or not present in households for three years due to reduced durability, and suggested a useful life of LLINs closer to two years than three years as in our study (Gnanguenon R, et al., 2014; Hakizimana E, et al., 2014; Ahogni IB, et al, 2020).

In the past, several studies have evaluated the effectiveness of different brands of LLINs in various geographic, socio-cultural and ecological areas in a research mode (Tan, K.R, et al., 2016; Käse, S.K, et al., 2014; Kawada, H, et al., 2014; Helinski, M.H, et al., 2015; Randriamaherijaona, S, et al., 2017). The durability of insecticides in this study for the three LLINs DawaPlus®2.0, PermaNet ${ }^{\circledR} 2.0$ and Yorkool® was excellent with average rates of mosquitoes falling on the back (knock-down) in 60 minutes greater than $80 \%$ in bio tests WHO cone tests at each follow-up and slightly higher average mortality rates in 24 hours, between $80 \%$ and $91 \%$ at 24 months. This results in an optimal insecticide efficacy of more than $70 \%$ after 2 years, in accordance with WHO criteria (WHO, 2013). This can be explained by the fact that the frequency of washing the nets was $\leq 20$ washes, which could have retained the active ingredient and therefore the net bio-efficiency.

\subsection{Limitations}

This study was conducted in research mode. Prospective design could lead to the Hawthorne 
effect, where being interviewed about the care and handling of nets several times during follow-up may have contributed to behavioral changes. The demonstrated efficacy of our LLINs is against the sensitive strains An. gambiae Kisumu, raised in the insectarium and whose sensitivity to pyrethroids is no longer proven. However, it has already been shown over a decade ago in our country that there was a significant level of resistance to pyrethroids for the dominant vector An. gambiae s.s (Gnanguenon V, et al., 2014). Consequently, the National malaria control program should opt for the purchase and the distribution of new generation LLIN, that is to say PermaNet 3.0 MILD with the addition of the synergist piperonyl butoxide (PBO).

\section{Conclusion}

After two years of monitoring with different urban and rural populations in the cities of Dogbo, Djougou and Ketou, in Benin, the LLIN PermaNet®2.0 in 100-denier polyester showed a lower physical survival than that of the LLIN DawaPlus ${ }^{\circledR} 2.0$ and Yorkool ${ }^{\circledR}$, both in 100 denier polyester. This suggests that the differences were due to environmental and behavioral characteristics and not to the brand of LLINs.

\section{Ethical clearance and informed consent}

This study received ethical approval (favorable ethical opinion n 05 of 07 November 2017) from the CREC Institutional Ethics Committee (IECC). All heads of households who were 18 years or older and who have received the DawaPlus ${ }^{\circledR} 2.0$, PermaNet ${ }^{\circledR} 2.0$ and Yorkool ${ }^{\circledR}$ LN nets under evaluation were voluntarily included in the study after signing the consent form and were able to withdraw if they wished without fear of retaliation.

\section{Conflict of interest}

The authors declare no conflict of interest.

\section{Reference}

Abbott's Formula (2004). In: Encyclopedia of Entomology. Springer, Dordrecht. https://doi.org/10.1007/0-306-48380-7_4

Ahogni, I. B., Salako, A. S., Akinro, B. et al. (2020). Physical integrity and survivorship of long-lasting insecticidal nets distributed to households of the same socio-cultural community in Benin, West Africa. Malar J., 19, 58. https://doi.org/10.1186/s12936-020-3138-7

Allan, R., O'Reilly, L., Gilbos, V., \& Kilian, A. (2012). An observational study of material durability of three World Health Organization-recommended long-lasting insecticidal nets in eastern Chad. The American journal of tropical medicine and hygiene, 87(3), 407-411. https://doi.org/10.4269/ajtmh.2012.11-0331

Ana, P. A., Emmanuel, O., Hannah, K. et al. (2020). Monitoring the durability of the long-lasting insecticidal nets MAGNet and Royal Sentry in three ecological zones of Mozambique. Malar J., 19, 209. https://doi.org/10.1186/s12936-020-03282-w

Azondekon, R., Gnanguenon, V., Oke-Agbo, F. et al. (2014). A tracking tool for long-lasting insecticidal (mosquito) net intervention following a 2011 national distribution in 
Benin. Parasites Vectors, 7, 6. https://doi.org/10.1186/1756-3305-7-6

Bhattarai, A., Ali, A. S., Kachur S. P., et al. (2007). Impact of artemisinin-based combination therapy and insecticide treated nets on malaria burden in Zanzibar. PLoS Med. 4, e309. https://doi.org/10.1371/journal.pmed.0040309

Emmanuel Obi, Festus Okoh, Sean Blaufuss, et al., (2020). Monitoring the physical and insecticidal durability of the long-lasting insecticidal net DawaPlus ${ }^{\circledR} 2.0$ in three States in Nigeria. Malar J., 19, 124. https://doi.org/10.1186/s12936-020-03194-9

Gnanguenon, V., Azondekon, R., Oke-Agbo, F. et al. (2014). Durability assessment results suggest a serviceable life of two, rather than three, years for the current long-lasting insecticidal (mosquito) net (LLIN) intervention in Benin. BMC Infect Dis, 14, 69. https://doi.org/10.1186/1471-2334-14-69

Haji, K. A., Khatib, B. O., Obi, E., et al. (2020). Monitoring the durability of the long-lasting insecticidal nets Olyset $^{\circledR}$ and PermaNet $^{\circledR} 2.0$ in similar use environments in Zanzibar. Malaria journal, 19(1), [187]. https://doi.org/10.1186/s12936-020-03258-w

Hakizimana, E., Cyubahiro, B., Rukundo, A. et al. (2014). Monitoring long-lasting insecticidal net (LLIN) durability to validate net serviceable life assumptions, in Rwanda. Malar J., 13, 344. https://doi.org/10.1186/1475-2875-13-344

Helinski, M.H., Namara, G., Koenker, H. et al. (2015). Impact of a behaviour change communication programme on net durability in eastern Uganda. Malar J., 14, 366. https://doi.org/10.1186/s12936-015-0899-5

Käse, S. K., \& Russell, S. J. (2014). Modes of hole formation in long-lasting insecticidal nets (LLINs) retrieved from South Eastern Ghana. Parasites Vectors, 7, 547. https://doi.org/10.1186/s13071-014-0547-x

Kawada, H., Ohashi, K., Dida, G. O. et al. (2014). Insecticidal and repellent activities of pyrethroids to the three major pyrethroid-resistant malaria vectors in western Kenya. Parasites Vectors, 7, 208. https://doi.org/10.1186/1756-3305-7-208

Kilian, A., Koenker, H., Obi, E. et al (2015). Field durability of the same type of long-lasting insecticidal net varies between regions in Nigeria due to differences in household behaviour and living conditions. Malar J., 14, 123. https://doi.org/10.1186/s12936-015-0640-4

Malaria Indicator Survey (MIS) 2017, Benin

Mansiangi, P., Umesumbu, S., Etewa, I., et al. (2020). Comparing the durability of the long-lasting insecticidal nets DawaPlus ${ }^{\circledR} 2.0$ and DuraNet $\odot$ in northwest Democratic Republic of Congo. Malaria journal, 19(1), [189]. https://doi.org/10.1186/s12936-020-03262-0

Randriamaherijaona, S., Raharinjatovo, J., \& Boyer, S. (2017). Durability monitoring of long-lasting insecticidal (mosquito) nets (LLINs) in Madagascar: physical integrity and insecticidal activity. Parasites Vectors, 10, 564. https://doi.org/10.1186/s13071-017-2419-7 


\section{Macrothink}

Sudhansu, S. S., Amol, V. K., Sonia, T., et al. (2020). Evaluation of bio-efficacy and durability of long-lasting insecticidal nets distributed by malaria elimination programme in Eastern India. Malar J., 19, 186. https://doi.org/10.1186/s12936-020-03260-2

Tan, K. R., Coleman, J., Smith, B. et al. (2016). A longitudinal study of the durability of long-lasting insecticidal nets in Zambia. Malar J., 15, 106. https://doi.org/10.1186/s12936-016-1154-4

Van Roey, K., Sovannaroth, S., Sochantha, T. et al. (2014). A phase III trial to evaluate the efficacy, fabric integrity and community acceptance of Netprotect ${ }^{\circledR}$ using a recommended long-lasting insecticidal net as positive control. Malar J., 13, 256. https://doi.org/10.1186/1475-2875-13-256

WHO cooperation strategy with Benin: 2016-2019 NMCP. 2011. Post-campaign evaluation of free LLIN distribution in 2011 in Benin, Cotonou. Ministry of Health. President's Malaria Initiative: LLIN durability monitoring. https ://www. durability monitoring .org/. Accessed 21 Nov 2019.

WHO. Estimating functional survival of long-lasting insecticidal nets from field data. Vector Control Technical Expert Group Report to MPAC September 2013. http://www.who.int/malar ia/mpac/mpac_sep13_vcteg_llin_survival_repor t.pdf. Accessed 6 Mar 2020.

WHO. Guidelines for laboratory and field testing of long-lasting insecticidal nets. Geneva: World Health Organization; 2013.

WHO. Guidelines for monitoring the durability of long-lasting insecticidal mosquito nets under operational conditions. WHO/HTM/NTD/WHOPES/2011.5 http://whqli bdoc.who.int/publi catio ns/2011/97892 41501 705_eng.pdf. Accessed 6 Mar 2020.

WHO. Pre-qualification team: pre-qualified vector control products. 17 July 2018. https ://www.who.int/pq-vecto r-contr ol/prequ alifi ed-lists / LOPrequali fiedProduc ts201 90411 .pdfua=1. Accessed 6 Mar 2020. https://doi.org/10.1201/b21759-1

WHO. Report of the 12th WHOPES working group meeting. Geneva: World Health Organization; 8-1 December 2008. WHO/HTM/NTD/ WHOPES/2009.1.

\section{Copyright Disclaimer}

Copyright for this article is retained by the author(s), with first publication rights granted to the journal.

This is an open-access article distributed under the terms and conditions of the Creative Commons Attribution license (http://creativecommons.org/licenses/by/4.0/). 